\title{
Colony morphology and molecular identification of Vibrio spp. on green mussels (Perna viridis) in Yogyakarta, Indonesia tourism beach areas
}

\author{
FARIDA HIKMAWATI, ARI SUSILOWATI", RATNA SETYANINGSIH \\ Bioscience Program, Postgraduate Program, Universitas Sebelas Maret. J1 Ir. Sutami 36 A Surakarta 57126, Central Java, Indonesia. \\ Tel/fax.: +62-271-6633375, `email: arisusilowati@staff.uns.ac.id
}

Manuscript received: 13 June 2019. Revision accepted: 8 September 2019.

\begin{abstract}
Hikmawati F, Susilowati A, Setyaningsih R. 2019. Colony morphology and molecular identification of Vibrio spp. on green mussels (Perna viridis) in Yogyakarta, Indonesia tourism beach areas. Biodiversitas 20: 2891-2899. Green mussels (Perna viridis) have filter feeder properties that allow pathogenic bacteria from the water environment to accumulate in relatively high levels. About $20 \%$ of foodborne diseases are caused by large quantities of seafood contaminated with bacteria. The purpose of this study is to determine the morphological characteristics, pathogenicity, identity, and the kinship of Vibrio species on green mussels in Yogyakarta coastal tourism areas. Vibrio spp. were grown on selective differential TCBS media. In this media, the suspected Vibrio spp. would produce yellow or green colonies. The ability of hemolysis of Vibrio was blood agar media, the species was molecularly identified using 16S rRNA gene sequence, and the phylogenetic relationship of the Vibrio spp., was analyzed using MEGA X Neighbor-Joining program. Based on morphological analysis, we obtained 23 bacterial isolates suspected to be Vibrio spp. Two Isolates $\left(\mathrm{L}_{1} \mathrm{~K}_{2} 6\right.$ and $\left.\mathrm{L}_{2} \mathrm{~K}_{2} 13\right)$ were positive for $\alpha$-hemolysis activity and 4 isolates $\left(\mathrm{L}_{1} \mathrm{~K}_{1} 3, \mathrm{~L}_{2} \mathrm{~K}_{1} 8, \mathrm{~L}_{2} \mathrm{~K}_{2} 16\right.$, and $\left.\mathrm{L}_{3} \mathrm{~K}_{2} 22\right)$ were positive for $\beta$-hemolysis activity. The molecular analysis involved 18 Vibrio species, and 4 of them represented the Vibrio genus and 14 species represented 97-99\% similarity species in accordance with the 16S rRNA sequence in database, namely: Vibrio alginolyticus, Vibrio parahaemolyticus, Vibrio cholerae, Vibrio neocaledonicus, Vibrio mimicus, Vibrio azureus, Vibrio diabolicus, Vibrio tapetis, Vibrio natriegens, and Vibrio owensii. The most dominant number of Vibrio isolates was V. alginolyticus, while the lowest was $V$. owensii. The highest number of Vibrio species in green mussels was found in Goa Cemara beach while the lowest was in Kwaru beach. Vibrio spp bacteria found in green clams in coastal tourism areas in Yogyakarta have close phylogenetic relationships with other Vibrio in seafood in Indonesian coastal waters.
\end{abstract}

Keywords: 16S rRNA gene sequence, filter feeders, foodborne diseases, Green mussels, TCBS media, Vibrio

\section{INTRODUCTION}

Yogyakarta Beach is the main culinary place that is visited by tourists. Green shellfish is a marine fishery product that is favored by tourists, tastes good and also has a high protein content. Green mussels (Perma viridis) are classified as soft-bodied animals (Phylum Mollusca). They are two-shelled animals and have a brownish-green color (Wati 2014). Green mussels have good nutritional values for consumption including $49.8 \%$ water, $15.5 \%$ fat, $18.5 \%$ carbohydrates, $4.3 \%$ ash, and $21.9 \%$ protein (Eshmat et al. 2014). Green mussels concentrate microorganisms from surrounding waters during the filter-feeding process, therefore microorganisms like pathogenic bacteria such as Vibrio spp. are easier to accumulate (Murdinah 2009).

Bacteria spread through seafood will lead to foodborne diseases. Foodborne diseases are diseases that occur after consuming seafood in very large quantities contaminated by pathogenic bacteria (BPOM 2008). The case of foodborne diseases can occur from a level that is not severe to the level of death. For example, foodborne diseases by Salmonella sp., Vibrio cholerae, and Clostridium botulinum. According to Davies et al. (2011), as many as $10-20 \%$ of cases of foodborne diseases transmitted through seafood are caused by the bacteria Vibrio spp. in large quantities Vibrio spp. is a type of bacteria that lives saprophytically in freshwater, seawater, and soil. These bacteria can also live in relatively high salinity of 20-40 ppt and will grow well in optimum $\mathrm{pH}$ conditions between 7.0 - 7.5 and optimum temperature growth of $37^{\circ} \mathrm{C}$ (Supardi and Sukamto 1999). Vibrio spp bacteria are gram-negative with a single cell form with a short stem that is bent (coma) or straight, the long size of the Vibrio spp bacteria. about 1,4-50nm and width 0,3-1,3, motile and have polar flagella (Felix et al. 2011).

Vibrio cholerae is often found in raw shrimp, raw fish, shellfish and fish. When $V$. cholerae enters the human body, they can cause foodborne disease. It is characterized by vomiting, diarrhea, dehydration (Kharirie 2013). Vibrio alginolyticus can be said to be a pathogenic bacteria that cause foodborne disease, it is proven that these bacteria result in gastroenteritis and peritonitis in humans, besides that they can also cause infection and lead to death (Campanelli 2008). Vibrio parahaemolyticus is flora in brackish water environment and one of the species Vibrio spp. which are pathogenic in commodity shrimp and in humans (De Paola et al. 2000). The presence of $V$. parahaemolyticus in fishery products causes foodborne diseases in humans through raw food consumption or imperfect processing. This can also be caused by crosscontamination between processed and raw foods or through washing with water containing $V$. parahaemolyticus (Daniels and Nicoll 2012).

The presence of a large number of $V$. parahaemolyticus 
is one of the causes of cases of septicemia and diarrhea in various regions of Southeast Asia (Merwad et al. 2011). Strains of $V$. parahaemolyticus that can cause disease are generally associated with the presence of virulence thermostable direct hemolysin (TDH) and thermostable direct hemolysin related hemolysin (TRH) factors. Thermostable Direct Hemolysin (TDH) is known as virulence factor because its $\beta$ hemolysis activity which can lyse red blood cells is characterized by the presence of a clear zone in the blood agar media.

From the above explanation, research findings are expected to be used as information about the existence of Vibrio spp. on green mussels and as consideration for the safety of public consumption. The purpose of this study is to determine the morphological characteristics, pathogenicity, molecular identification, and kinship of Vibrio spp that can be expected to lead foodborne disease in green mussels found in the Yogyakarta coastal tourism area.

\section{MATERIALS AND METHODS}

\section{Samples collection}

The sampling was conducted on May 2018, taking place on three Yogyakarta, Indonesia tourist beach stations, namely, Depok Beach, Goa Cemara Beach, and Kwaru Beach with three conditions namely fresh, not fresh, and already through the cooking process. Nine samples of green mussels were taken at each beach site. The samples are then neatly stored into a sterile plastic clip containing the location and the condition of the shell after they were put into a Cooler Box containing Ice Gel. The samples were further tested for their pathogenicity, molecular identity and phylogenetic relationship at the Microbiology and Genetics Laboratory of Sebelas Maret University, Surakarta, Indonesia.

\section{Isolation of Vibrio}

Isolation is carried out in sterile rooms and conditions and uses personal protective equipment, so data is accurate. Samples of green mussels are removed from the shell carefully and remain sterile and then crushed by using sterile mortar until they are completely smooth. All parts of the green mussel organ are used because the size of the shells is less than $3 \mathrm{~cm}$ (Fitriatin and Manan 2015). The sample was diluted with three series of dilutions namely: $10^{-1}, 10^{-2}$, and $10^{-3}$ use sterile aquadest, the sample is distributed by using a spread plate technique on sterile petri dishes using TCBS media namely selective media for Vibrio bacteria. The isolated samples were then wrapped in sterile paper and incubated at $37^{\circ} \mathrm{C}$ for 48 hours in the upside-down position. Furthermore, the colonies that grew on the media were taken by using sterile osseous needles and inoculated on TCBS media and then incubated again at $37^{\circ} \mathrm{C}$ for 18 hours (Wayan 2015).

\section{The morphological character of colonies of Vibrio}

For detail morphological characterization, the colonies were taken using inoculation needles and transferred. with streak plate technique, into TCBS agar medium for further purification and then incubated at $37^{\circ} \mathrm{C}$. The pure colony was morphologically observed under a microscope. The characteristics that were observed including colony shape, color, size, edge, elevation (colony surface shape) and texture (Hidayat 2013).

\section{Pathogenicity of Vibrio}

Pathogenic bacteria suspected of being Vibrio bacterial isolates found in green mussels were carried out by using the hemolysis test in blood agar media (BAP). Media for blood or blood agar plate (BAP) is a growth medium for Vibrio bacteria that can distinguish pathogenic bacteria based on the effects of bacterial hemolytic exotoxins on red blood cells. Vibrio isolates were inoculated with streak plate technique on BAP media and then incubated in a place and sterile condition for 4 hours at $37^{\circ} \mathrm{C}$. Hemolysis activity is indicated by the zone of hemolysis in the BAP media which is seen when the light is on from behind. There are three types of hemolysis that could appear, namely $\beta$-hemolysis (when there is no zone of hemolysis around the growing colonies), $\alpha$-hemolysis (some blood cells found in the zone of hemolysis or the presence of greenish discoloration around the colonies) and $\varepsilon$-hemolysis (no hemolysis) (Buxton 2003).

\section{Genomic DNA extraction, DNA qualification, and quantification of Vibrio.}

The DNA extraction was carried out using Presto ${ }^{\mathrm{TM}}$ Mini gDNA Bacteria Kit (Geneaid). The measurement of DNA quantity was carried out by using a bio-photometer at wavelengths of $\lambda 260 \mathrm{~nm}$ and $\lambda 280 \mathrm{~nm}$. The purity of DNA can be measured by calculating the absorbance value on $\lambda 260 \mathrm{~nm}$ with $\lambda 280 \mathrm{~nm}$ (Ratio $\lambda 260: \lambda 280$ ). As much as 10 $\mu \mathrm{L}$ sterile aqua bidest was poured into cuvet in biophotometer, then the blank button was pressed until number 0.0 appeared. Next, $1 \mu \mathrm{L}$ aqua bidest was removed and replaced with $1 \mu \mathrm{L}$ DNA. DNA was said to be pure and free of contamination if the ratio of absorbance ranges from 1.8 - 2.0 (Hasrida et al. 2016).

\section{Amplification of 16S rRNA gene}

Molecular identification was carried out by amplifying the 16S rRNA encoding gene using the PCR technique. The PCR reaction consisted of My $\mathrm{Taq}^{\mathrm{TM}} \mathrm{HS}$ Red Mix PCR, $1 \mu \mathrm{L}$ DNA template (100 ng), $2 \mu \mathrm{L}$ primers with a concentration of 10 pmol (63 Forward and 1387 Reverse), and $\mathrm{ddH}_{2} \mathrm{O}$ was added to a total volume of $25 \mu \mathrm{L}$. The used universal primer were pair of Forward 16S rRNA 63F (5'CAGGCCTAACACATGCAAGTC3') and reverse 1387R (5'GGGCGG WGTGTACAAGGC3') (Marchesi et al. 1998). The amplification was carried out in the following conditions: predenaturation at $94^{\circ} \mathrm{C}$ for $5 \mathrm{~min}, 30$ cycles of denaturation at $94^{\circ} \mathrm{C}$ for 30 seconds, annealing at $53^{\circ} \mathrm{C}$ for 45 seconds, extension at $72^{\circ} \mathrm{C}$ for 1,5 minutes, and a final extension at $72^{\circ} \mathrm{C}$ for 5 minutes. PCR products were then electrophoresed.

\section{DNA electrophoresis}

As much as $2 \mu \mathrm{L}$ loading dye as ballast and dye were mixed with $4 \mu \mathrm{L}$ PCR products on parafilm. The solution was then inserted into a well made $1 \%$ agarose gel and 
soaked in a buffer solution (50 ml TAE $10 \mathrm{X}$ solution +950 $\mathrm{ml}$ sterile aqua dest) in the electrophoresis tank. The tank was then closed and connected to the power supply. The electrophoresis was run for 1.5 hours with Voltage $90 \mathrm{~V}$. The agarose which has passed running process was soaked in ethidium bromide solution for 15 minutes and then soaked again in aqua dest for 10 minutes, afterward observation of DNA migration was carried out using UV transilluminator on Gel Doc (Fatchiyah et al. 2011).

\section{Sequencing}

And sequenced. Next, the sequencing results were analyzed by comparing the sequence on the database in the NCBI (National Center for Biotechnology Information) with the Basic Local Alignment Search Tool (BLAST) (Ilmiah et al. 2012).

\section{Phylogenetic analysis}

The phylogenetic relationship was inferred using the Neighbor-Joining method. The percentage of replicate trees in which the associated taxa clustered together in the bootstrap test (500 replicates) were shown next to the branches. The tree was drawn to scale, with branch lengths in the same units as those of the distances used to infer the phylogenetic tree. The distances were computed using the p-distance method and were in the units of the number of base differences per site. Phylogenetic relationship analyses were conducted in MEGA X software (Kumar et al. 2018).

\section{RESULTS AND DISCUSSION}

\section{Morphological characteristics of suspected Vibrio spp colony}

Based on visual observations of Vibrio spp. Which is found in shellfish in the coastal tourism area of Yogyakarta,
Vibrio bacteria can be distinguished based on the color, shape, and size of colonies that grow on TCBS media. Vibrio spp. What was found was divided into two groups, namely the group that could ferment sucrose collected with yellow colonies and secondly, Vibrio spp. groups that cannot ferment sucrose are characterized by green colonies (Figure 1). Strengthened by the research of Mailoa and Sehtha (2011) which proved the color of green colonies in Vibrio is due to the nature of bacteria that cannot ferment sucrose, while the Vibrio yellow colony is able to ferment sucrose and can reduce $\mathrm{pH}$ on TCBS media.

Bacterial colonies in green mussel samples showed detection of Vibrio spp. in sufficient quantities. The highest number of bacteria is Vibrio spp. on Depok beach with non-fresh shellfish conditions with bacterial colonies of $0.686 \times 10^{5} \mathrm{CFU} / \mathrm{g}$, while the lowest bacterial colonies with bacterial colonies of $0.002 \times 10^{5} \mathrm{CFU} / \mathrm{g}$ on Kwaru beach locations with boiled shells (Farida et al. 2019). All grown bacterial colony were grouped based on their morphological characteristics. In total, there are 23 bacterial isolates suspected as Vibrio colony were grouped based on their similarity of the macroscopic characteristics (Table 1). Morphological observations of bacterial colony show that all bacterial colony is circular, yellow or green color and the size of the diameter of bacterial colonies range from 2-5 $\mathrm{mm}$. These characteristics are typical Vibrio colony. Some bacterial colonies found in the coastal tourism area of Yogyakarta have different morphologies as soon as they are green, but some are yellow in Depok beach, Goa Cemara, and Kwaru. While the conditions are not fresh, the morphology of the Vibrio bacteria found is yellow on the Depok coast and Goa Cemara beach, while the Kwaru beach is mostly green. Boiled green mussels besides a small amount for Vibrio are found to have green morphology on the beaches of Depok and Kwaru, and yellow policies on the Goa Cemara beach.

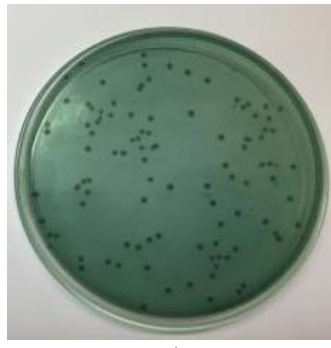

A

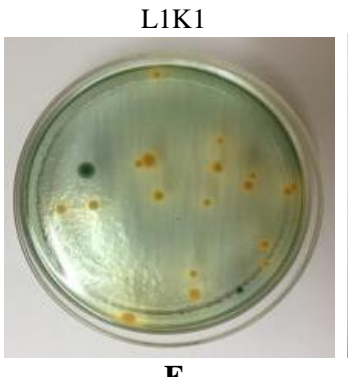

L2K3

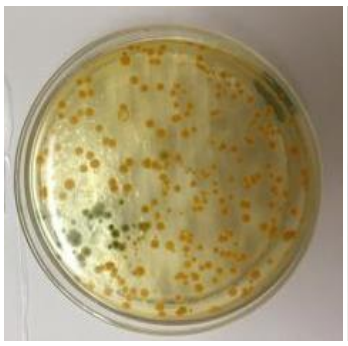

B

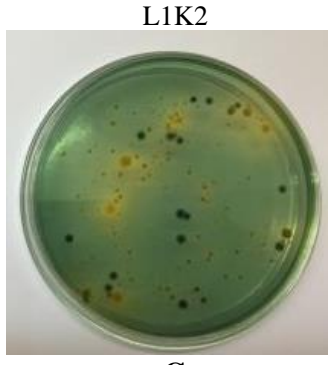

G

L3K1

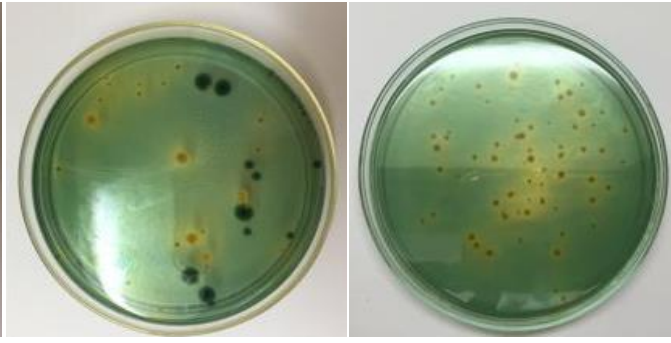

D

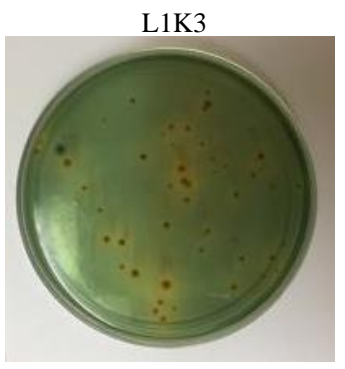

H

L3K2

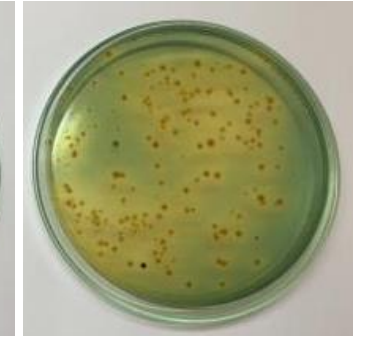

$\mathbf{E}$ L2K2

Figure 1. Morphology of 23 colonies of Vibrio isolates in green mussels (Perna viridis) found in the Yogyakarta, Indonesia coastal tourism. Note: $\mathrm{L}_{1}$ : Depok Beach, L2: Goa Cemara Beach, L3: Kwaru Beach and $\mathrm{K}_{1}$ : Fresh, $\mathrm{K}_{2}$ : Not Fresh, $\mathrm{K}_{3}$ : Boiled 
Table 1. Morphological characteristics of the suspected Vibrio spp. Isolates in samples of green mussels (Perna viridis) found in the Yogyakarta coastal tourism

\begin{tabular}{|c|c|c|c|c|c|c|}
\hline Location & Isolate code & Colony color & Colony form & $\begin{array}{c}\text { Elevation of } \\
\text { the colony }\end{array}$ & $\begin{array}{c}\text { Size of the } \\
\text { colony }(\mathrm{mm})\end{array}$ & $\begin{array}{c}\text { Edge of the } \\
\text { colony }\end{array}$ \\
\hline \multirow[t]{7}{*}{ Depok Beach } & $\mathrm{L}_{1} \mathrm{~K}_{1} 1$ & Yellow & Circular & Raised & 3 & Entire \\
\hline & $\mathrm{L}_{1} \mathrm{~K}_{1} 2$ & Green & Circular & Raised & 3 & Calendar \\
\hline & $\mathrm{L}_{1} \mathrm{~K}_{1} 3$ & Bluish Green & Circular & Umbonate & 2 & Entire \\
\hline & $\mathrm{L}_{1} \mathrm{~K}_{2} 4$ & Green Transparent & Circular & Flat & 3 & Entire \\
\hline & $\mathrm{L}_{1} \mathrm{~K}_{2} 5$ & Bluish Green & Circular & Umbonate & 5 & Entire \\
\hline & $\mathrm{L}_{1} \mathrm{~K}_{2} 6$ & Deep Yellow & Circular & Convex & 5 & Entire \\
\hline & $\mathrm{L}_{1} \mathrm{~K}_{2} 7$ & Green & Circular & Convex & 2 & Entire \\
\hline Goa Cemara & $\mathrm{L}_{2} \mathrm{~K}_{1} 8$ & Yellow & Circular & Raised & 2 & Entire \\
\hline \multirow[t]{8}{*}{ Beach } & $\mathrm{L}_{2} \mathrm{~K}_{1} 9$ & Deep Yellow & Circular & Convex & 4 & Calendar \\
\hline & $\mathrm{L}_{2} \mathrm{~K}_{2} 10$ & Deep Yellow & Circular & Convex & 2 & Entire \\
\hline & $\mathrm{L}_{2} \mathrm{~K}_{2} 11$ & Green & Circular & Convex & 3 & Entire \\
\hline & $\mathrm{L}_{2} \mathrm{~K}_{2} 12$ & Bluish Green & Circular & Unbonate & 2 & Entire \\
\hline & $\mathrm{L}_{2} \mathrm{~K}_{2} 13$ & Yellow & Circular & Raised & 2 & Entire \\
\hline & $\mathrm{L}_{2} \mathrm{~K}_{2} 14$ & Deep Yellow & Circular & Convex & 3 & Entire \\
\hline & $\mathrm{L}_{2} \mathrm{~K}_{2} 15$ & Green & Circular & Convex & 2 & Entire \\
\hline & $\mathrm{L}_{2} \mathrm{~K}_{2} 16$ & Bluish Green & Circular & Umbonate & 2 & Entire \\
\hline \multirow[t]{7}{*}{ Kwaru Beach } & $\mathrm{L}_{3} \mathrm{~K}_{1} 17$ & Deep Yellow & Circular & Convex & 5 & Entire \\
\hline & $\mathrm{L}_{3} \mathrm{~K}_{1} 18$ & Deep Yellow & Circular & Flat & 3 & Calendar \\
\hline & $\mathrm{L}_{3} \mathrm{~K}_{1} 19$ & Yellow & Circular & Flat & 2 & Calendar \\
\hline & $\mathrm{L}_{3} \mathrm{~K}_{2} 20$ & Yellow & Circular & Flat & 2 & Entire \\
\hline & $\mathrm{L}_{3} \mathrm{~K}_{2} 21$ & Bluish Green & Circular & Convex & 3 & Entire \\
\hline & $\mathrm{L}_{3} \mathrm{~K}_{2} 22$ & Deep Yellow & Circular & Convex & 5 & Entire \\
\hline & $\mathrm{L}_{3} \mathrm{~K}_{2} 23$ & Yellow & Circular & Convex & 2 & Calendar \\
\hline
\end{tabular}

Note: (L1: Depok Beach, L2: Goa Cemara Beach, L3: Kwaru Beach and $K_{1}$ : Fresh, K2: Not Fresh, K3: Boiled)

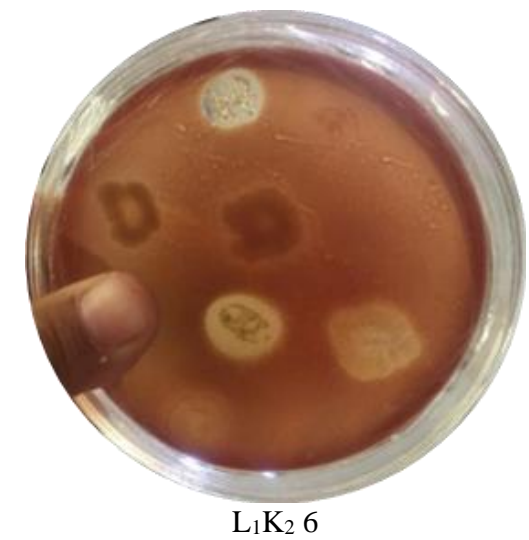

Figure 2. Hemolysis zone appears in the hemolysis test of Vibrio spp. $\mathrm{L}_{1} \mathrm{~K}_{2}$

There are some types of Vibrio colonies in green mussels which are the result of various factors such as temperature, conductivity, acidity ( $\mathrm{pH})$, dissolved oxygen, and total available organic matter (Ilmiah et al. 2012). These factors affect the bacterial colony to maintain their survival. If green mussels are in different conditions or places, the types and numbers of Vibrio found in an area are likely to be different. Other factors that also influence the bacterial presence are competition for food in the region and interaction between Vibrio with other species there (Yital et al. 2007).

\section{Pathogenicity of Vibrio spp.}

Isolates with positive hemolytic activity showed the type of $\beta$-hemolysis and $\alpha$-hemolysis can be seen in (Figure 2) which was marked by a clear zone in the surrounding colonies one example of Depok beach with a condition that is not fresh. The figure shows the formation of a lysis zone that clearly shows that isolates can lyse red blood cells. Really clear. The imperfect hemolysis process shows greenish-colored media, the imperfect or unreal lysis process causes no change in color in the media (Suryanto 2007).

Based on the results of pathogenicity test of Vibrio spp. in 23 isolates, 6 isolates showed a positive hemolysis activity, namely: isolates $\mathrm{L}_{1} \mathrm{~K}_{1} 3, \mathrm{~L}_{1} \mathrm{~K}_{2} 6, \mathrm{~L}_{2} \mathrm{~K}_{1} 8, \mathrm{~L}_{2} \mathrm{~K}_{2} 13$, $\mathrm{L}_{2} \mathrm{~K}_{2} 16, \mathrm{~L}_{3} \mathrm{~K}_{2} 22$ (Table 2). Bacterial colonies of $\mathrm{L}_{1} \mathrm{~K}_{1} 3$ and $\mathrm{L}_{2} \mathrm{~K}_{2} 16$ isolates have a bluish-green colony. While bacterial colonies $\mathrm{L} 1 \mathrm{~K} 26, \mathrm{~L}_{2} \mathrm{~K}_{1} 8, \mathrm{~L}_{2} \mathrm{~K}_{2} 13$, and $\mathrm{L}_{3} \mathrm{~K}_{2} 22$ isolates have a yellow colony. The hemolysis test performed on blood agar media showed a different type of lysis. Qualitatively, the clear zone can be classified into three classes of lysis, and what was obtained in this research showed two classes of lysis. The first was $\alpha$ hemolysis with medium lysis zone which had more different colors than other isolates. This including isolates with code $\mathrm{L}_{1} \mathrm{~K}_{2} 6$ and $\mathrm{L}_{2} \mathrm{~K}_{2}$ 13. The second was $\beta$ hemolysis with a very powerful lysis zone where the isolate shows a very wide lysis zone indicated in isolates with code $\mathrm{L}_{1} \mathrm{~K}_{1} 3, \mathrm{~L}_{2} \mathrm{~K}_{1} 8, \mathrm{~L}_{2} \mathrm{~K}_{2} 16$, and $\mathrm{L}_{3} \mathrm{~K}_{2} 22$. Most of the bacteria that have the ability to hemolysis, namely Vibrio bacteria found in green mussels in a condition that is not 
fresh and on the beach location of Goa Cemara. While in fresh conditions only a few of the total bacteria. Where both locations have bacteria with different hemolysis abilities.

Bacteria with $\beta$-hemolysis have the ability to multiply faster in the digestive tract compared to $\alpha$-hemolysis. This ability is an important factor in determining the virulence from Vibrio spp. The production of enterotoxin in both $\beta$ hemolysis and $\alpha$-hemolysis can determine the pathogenicity. The strain with $\beta$-hemolysis can last longer than $\alpha$-hemolysis.

The occurrence of foodborne disease is closely related to the pathogenicity factors of the bacteria, the ability to invade tissues, colonization, the speed of proliferation of pathogens, and host defenses system against pathogens (Tortora et al. 2001). The hemolytic activity makes the bacterial defense factors attack host defenses by lysing the host's blood cells. Bacteria that are able to survive will enter the bloodstream so that they spread to all cells of the host's body and the target organ (Fitriatin and Manan 2015).

\section{PCR Amplification of 16S rRNA gene}

The gel electrophoresis shows that the 20 suspected Vibrio band's size is 1300 bp. Each amplified bacterial culture isolate was observed and documented in GelDoc. According to (Marchesi et al. 1998), if 16S rRNA gene of bacteria has been correctly amplified, then the length of the PCR product would be around \pm 1300 bp (Figure 3 ).

The sequence analysis from the database in GenBank shows that 18 of the 20 isolates were identified to have similarities to the genus Vibrio and 2 isolates have similarities to the genus Staphylococcus. From 18 isolates, 10 different types of Vibrio species are found to have the $97-99 \%$, similarity of $16 \mathrm{~S}$ rRNA with Vibrio namely: $V$. alginolyticus, $V$. parahaemolyticus, $V$. cholerae, $V$. neocaledonicus, V. mimicus, V. azureus, V. diabolicus, V. tapetis, V. natriegens, and V. owensii (Table 3). Hagstrom et al. (2000) stated that isolates with a 16S rRNA sequence similarity greater than $97 \%$ could represent the same species.

Table 2. Hemolysis test results of Vibrio bacteria in green mussels found in the Yogyakarta coastal tourism area

\begin{tabular}{lcccc}
\hline Location & $\begin{array}{c}\text { Isolate } \\
\text { code }\end{array}$ & $\begin{array}{c}\text { Hemolysis } \\
\text { zone }\end{array}$ & $\begin{array}{c}\text { Size of the } \\
\text { hemolysis } \\
\text { zone }(\mathbf{m m})\end{array}$ & $\begin{array}{c}\text { Type of } \\
\text { hemolysis }\end{array}$ \\
\hline Depok & $\mathrm{L}_{1} \mathrm{~K}_{1} 1$ & - & - & - \\
Beach & $\mathrm{L}_{1} \mathrm{~K}_{1} 2$ & - & - & - \\
& $\mathrm{L}_{1} \mathrm{~K}_{1} 3$ & +++ & 1,85 & $\beta$-hemolysis \\
& $\mathrm{L}_{1} \mathrm{~K}_{2} 4$ & - & - & - \\
& $\mathrm{L}_{1} \mathrm{~K}_{2} 5$ & - & - & - \\
& $\mathrm{L}_{1} \mathrm{~K}_{2} 6$ & ++ & 1,57 & $\alpha$-hemolysis \\
& $\mathrm{L}_{1} \mathrm{~K}_{2} 7$ & - & - & - \\
Goa & $\mathrm{L}_{2} \mathrm{~K}_{1} 8$ & +++ & 1,96 & $\beta$-hemolysis \\
Cemara & $\mathrm{L}_{2} \mathrm{~K}_{1} 9$ & - & - & - \\
Beach & $\mathrm{L}_{2} \mathrm{~K}_{2} 10$ & - & - & - \\
& $\mathrm{L}_{2} \mathrm{~K}_{2} 11$ & - & - & - \\
& $\mathrm{L}_{2} \mathrm{~K}_{2} 12$ & - & - & - \\
& $\mathrm{L}_{2} \mathrm{~K}_{2} 13$ & ++ & 1,86 & $\alpha$-hemolysis \\
& $\mathrm{L}_{2} \mathrm{~K}_{2} 14$ & - & - & - \\
& $\mathrm{L}_{2} \mathrm{~K}_{2} 15$ & - & - & - \\
& $\mathrm{L}_{2} \mathrm{~K}_{2} 16$ & +++ & 2,11 & $\beta$-hemolysis \\
Kwaru & $\mathrm{L}_{3} \mathrm{~K}_{1} 17$ & - & - & - \\
Beach & $\mathrm{L}_{3} \mathrm{~K}_{1} 18$ & - & - & - \\
& $\mathrm{L}_{3} \mathrm{~K}_{1} 19$ & - & - & - \\
& $\mathrm{L}_{3} \mathrm{~K}_{2} 20$ & - & - & - \\
& $\mathrm{L}_{3} \mathrm{~K}_{2} 21$ & - & - & - \\
& $\mathrm{L}_{3} \mathrm{~K}_{2} 22$ & +++ & 1,88 & $\beta$-hemolysis \\
& $\mathrm{L}_{3} \mathrm{~K}_{2} 23$ & - & - & - \\
\hline
\end{tabular}

Note: "+++": very strong lysis zone, "++": Shows moderate lysis zone, "+": weak lysis zone, and "-“: Shows negatife hemolysis.

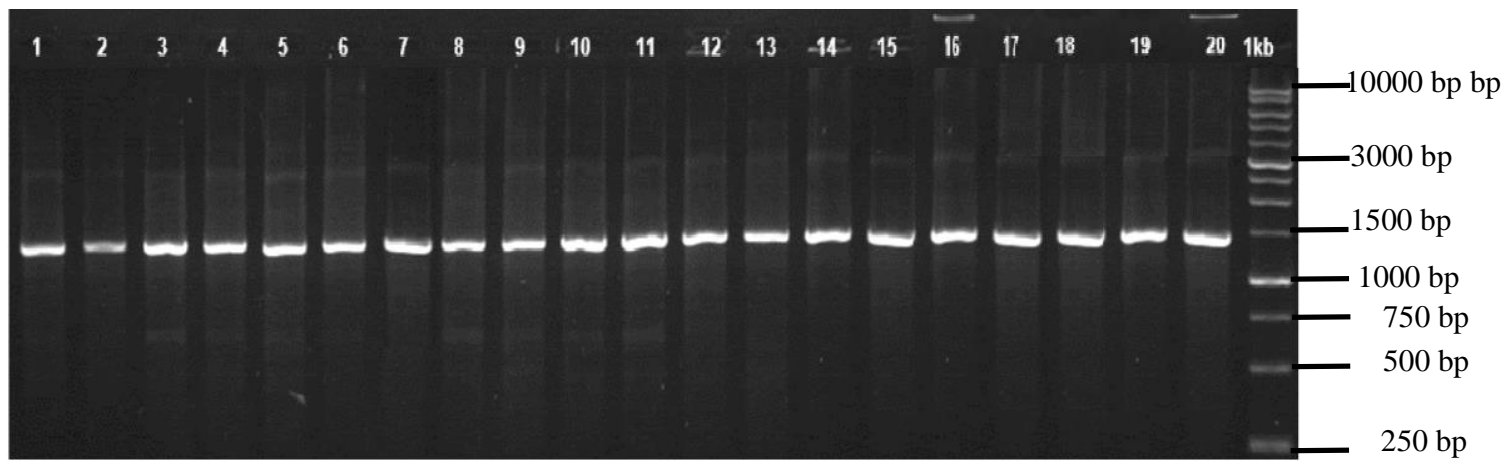

Condition:

Amount of DNA ladder loaded per lane The volume of sample loaded per lane $1 \mathrm{~Kb}$ DNA ladder (bp)

$1 \mathrm{~Kb}$ DNA ladder $(\mathrm{ng} / 0,1 \mu \mathrm{g})$
$0.8 \%$ Agarose gel

$0.1 \mu \mathrm{g}$ Each

$1 \mu \mathrm{L}$ Each

250500750100015002000250030004000500060008000

964.618 .446 .86 .818 .43 .65 .65 .65 .6

Figure 3. 16S rRNA gene electrophoresis gel from isolates of suspected Vibrio spp. in samples of green mussels found in the Yogyakarta coastal tourism area (amplified using $63 \mathrm{~F}$ and $1387 \mathrm{R}$ primers) 
Table 3. Isolate of Vibrio spp. detected in the samples of green mussels found in the Yogyakarta coastal tourism area, identified using 16S rRNA gene sequence (around $1300 \mathrm{bp}$ ).

\begin{tabular}{|c|c|c|c|c|c|c|c|c|}
\hline Location & $\begin{array}{l}\text { Isolate } \\
\text { code }\end{array}$ & Description & $\begin{array}{l}\text { Max } \\
\text { score }\end{array}$ & $\begin{array}{l}\text { Total } \\
\text { score }\end{array}$ & $\begin{array}{l}\text { Query } \\
\text { cover } \\
(\%)\end{array}$ & $\begin{array}{l}\text { E- } \\
\text { value }\end{array}$ & $\begin{array}{l}\text { Indent } \\
(\%)\end{array}$ & Accession \\
\hline Depok & $\mathrm{L}_{1} \mathrm{~K}_{1} 1$ & Vibrio neocaledonicus strain Xmb064 & 2028 & 2028 & 96 & 0.0 & 97 & KT986172.1 \\
\hline \multirow[t]{5}{*}{ Beach } & $\mathrm{L}_{1} \mathrm{~K}_{1} 3$ & Vibrio parahaemolyticus strain AP407 & 1973 & 1973 & 88 & 0.0 & 99 & MG575451.1 \\
\hline & $\mathrm{L}_{1} \mathrm{~K}_{2} 4$ & Vibrio mimicus strain AAMH02 & 2150 & 2150 & 92 & 0.0 & 98 & KC549802.1 \\
\hline & $\mathrm{L}_{3} \mathrm{~K}_{1} 5$ & Vibrio parahaemolyticus strain $\mathrm{SC} 2$ & 1967 & 1967 & 88 & 0.0 & 98 & MK308579.1 \\
\hline & $\mathrm{L}_{1} \mathrm{~K}_{2} 6$ & Vibrio alginolyticus strain $h q-\mathrm{V} 141$ & 1967 & 1967 & 88 & 0.0 & 98 & MH553008.1 \\
\hline & $\mathrm{L}_{1} \mathrm{~K}_{2} 7$ & Vibrio azureus strain ECSMC16 & 1993 & 1993 & 95 & 0.0 & 97 & KC210817.1 \\
\hline Goa & $\mathrm{L}_{2} \mathrm{~K}_{1} 8$ & Vibrio cholerae strain NIOT VC 06 & 2150 & 2150 & 92 & 0.0 & 98 & MF692792.1 \\
\hline Cemara & $\mathrm{L}_{2} \mathrm{~K}_{1} 9$ & Vibrio diabolicus strain WAB2224 & 1967 & 1967 & 88 & 0.0 & 98 & MH169294.1 \\
\hline \multirow[t]{5}{*}{ Beach } & $\mathrm{L}_{2} \mathrm{~K}_{2} 10$ & Vibrio alginolyticus strain WAB2135 & 1969 & 1969 & 88 & 0.0 & 98 & MH169336.1 \\
\hline & $\mathrm{L}_{2} \mathrm{~K}_{2} 11$ & Vibrio tapetis strain $\mathrm{P} 1$ & 2148 & 2148 & 92 & 0.0 & 98 & KU750805.1 \\
\hline & $\mathrm{L}_{2} \mathrm{~K}_{2} 13$ & Vibrio cholerae strain CECT 514 & 2145 & 2145 & 92 & 0.0 & 98 & NR044853.1 \\
\hline & $\mathrm{L}_{2} \mathrm{~K}_{2} 14$ & Vibrio neocaledonicus strain CV (H) 31 & 2109 & 2109 & 95 & 0.0 & 98 & MH643641.1 \\
\hline & $\mathrm{L}_{2} \mathrm{~K}_{2} 16$ & Vibrio parahaemolyticus strain $\mathrm{Vp}$-x10 & 1967 & 1967 & 88 & 0.0 & 98 & MH298548.1 \\
\hline Kwaru & $\mathrm{L}_{3} \mathrm{~K}_{1} 17$ & Vibrio alginolyticus strain hq-V173 & 1993 & 1993 & 95 & 0.0 & 97 & MH553013.1 \\
\hline \multirow[t]{6}{*}{ Beach } & $\mathrm{L}_{1} \mathrm{~K}_{2} 18$ & Vibrio cholerae strain DL1 & 2150 & 2150 & 92 & 0.0 & 98 & MG062857.1 \\
\hline & $\mathrm{L}_{3} \mathrm{~K}_{1} 19$ & Staphylococcus saprophyticus strain B9 & 2170 & 2170 & 92 & 0.0 & 99 & MK073020.1 \\
\hline & $\mathrm{L}_{3} \mathrm{~K}_{2} 20$ & Vibrio natriegens strain BPRIST057 & 2028 & 2028 & 96 & 0.0 & 97 & JF700507.1 \\
\hline & $\mathrm{L}_{3} \mathrm{~K}_{2} 21$ & Vibrio owensii strain F77007 & 2026 & 2026 & 96 & 0.0 & 97 & HQ908739.1 \\
\hline & $\mathrm{L}_{3} \mathrm{~K}_{2} 22$ & Vibrio alginolyticus strain Va-x 15 & 1973 & 1973 & 88 & 0.0 & 98 & MH298577.1 \\
\hline & $\mathrm{L}_{3} \mathrm{~K}_{2} 23$ & Staphylococcus xylosus strain CMU-BE04 & 2170 & 2170 & 92 & 0.0 & 99 & KX235339.1 \\
\hline
\end{tabular}

Note: $\mathrm{L}_{1}$ : Depok Beach, $\mathrm{L}_{2}$ : Goa Cemara Beach, $\mathrm{L}_{3}$ : Kwaru Beach and $\mathrm{K}_{1}$ : Fresh, $\mathrm{K}_{2}$ : Not Fresh, K 3 : Boiled

The isolates L1K2 6, L2K2 10, L3K117, L3K2 22, L2K1 8, L2K2 13, L1K2 18, L1K1 1, L2K2 14, L2K1 9, and L3K2 20 are yellow-colored colony which have 9798\% similarities with the 5 Vibrio species, namely: $V$. alginolyticus, $V$. cholerae, $V$. neocaledonicus, $V$. diabolicus, and $V$. natriegens. V. alginolyticus can be said to be a pathogenic bacterium that causes gastroenteritis and peritonitis in humans, besides that it can also cause an infection that leads to death in immuno-compromised patients (Campanelli 2008). When V. cholerae enters the human body, it could cause foodborne disease which is characterized by vomit, diarrhea, and dehydration (Kharirie 2013).

The green colonies are L1K1 3, L3K1 5, L2K2 16, L1K2 4, L1K2 7, L2K2 11, and L3K2 21 which have 9799\%. similarities with the also 5 Vibrio species that are $V$. parahaemolyticus, V. mimicus, V. azureus, V. tapetis, and $V$. owensii. This Vibrio belong to a pathogenic organism and can trigger foodborne disease because these bacteria can produce hemolysin. Seafood that contains $V$. mimicus, when is consumed directly in raw condition or cooked imperfectly, it can cause gastroenteritis and diarrhea (Spira et al. 1984). V. parahaemolyticus in fishery products causes foodborne diseases in humans through raw food consumption or imperfect processing (Lutz et al. 2013). This can also be caused by contamination of instant foods, raw foods, or by washing food with water contaminated with V. parahaemolyticus (Daniels and Nicoll 2012).

The highest type of Vibrio species in green mussels was found in Goa Cemara beach while the lowest was in Kwaru beach. From 10 types of Vibrio obtained in green clams, $V$. alginolyticus was found in all sampling locations in
Yogyakarta coastal areas. The most dominant number of bacterial isolates is $V$. alginolyticus, and the second ones are $V$. parahaemolyticus, $V$. cholerae, Vibrio neocaledonicus and while the lowest is Vibrio owensii.

\section{Phylogenetic analysis}

Phylogenetic analysis of nucleotide sequences will usually be an important area in sequence analysis. Phylogenetic trees make branches that connect taxonomic unit points, such as species or genes, and the tree roots are points that act as ancestors for all organisms which are being analyzed (Felix et al. 2011). Phylogenetic relationship on those identified 18 Vibrio spp that are found in green mussels in the coastal tourism area of Yogyakarta is determined and shown in the phylogenic tree. Phylogenetic relationship was constructed by using the Neighbor-Joining method to correctly identify the tree in the neighboring position and also have branches as close as possible. The Vibrio species in this research were analyzed for their kinship relationship with other Vibrio species found in previous research.

In the phylogenetic tree Vibrio bacteria found in green mussels in the coastal tourism area of Yogyakarta can be seen trees showing two large groups (Figure 4), the first group was branched first, namely bacteria $V$. alginolyticus $\mathrm{L}_{1} \mathrm{~K}_{2} 6$, V. alginolyticus $\mathrm{L}_{3} \mathrm{~K}_{1} 17$, V. alginolyticus $\mathrm{L}_{3} \mathrm{~K}_{2} 22$, dan $V$. alginolyticus $\mathrm{L}_{2} \mathrm{~K}_{2} 10$ which was found in green mussels appeared to have a kinship relationship with the bacteria found in previous studies, namely strains $V$. alginolyticus strains of ATCC 17749 which cause foodborne diseases found in seafood. Based on the results of molecular identification, V. alginolyticus is obtained 
with a homology level of $97-98 \%$ with a base length around 1300bp. the group found in this first branch has a similar morphology of yellow bacterial colonies. These bacteria are gram-negative, the catalase is positive, the oxidase is positive and belongs to the motile bacteria (Buwono 2004). Deadly toxins produced by $V$. alginolyticus strain Swy are originally isolated from diseased Curuma shrimp purified with Fast Protein Liquid Chromatography with the interaction of Hydrophobic (Phenyl Sepharose High Performance) chromatography and gel filtration columns. The toxin is an alkaline serine protease, showing maximum activity at $\mathrm{pH}$ 8-11 (Liu and Lee 1999).

Vibrio cholerae $\mathrm{L}_{2} \mathrm{~K}_{2} 13, V$. cholerae $\mathrm{L}_{2} \mathrm{~K}_{1} 8$, and $V$. cholerae $\mathrm{L}_{1} \mathrm{~K}_{2} 18$ which was found in green mussels appeared to have a kinship relationship with the bacteria found in previous studies, namely strains $V$. cholerae strain
V6. $V$. cholerae has yellow morphological features, including gram-negative bacteria, non-spores, facultative anaerobic life, and flagella. Clinical manifestations in the form of the disease will arise if a number of entering bacteria reach a certain amount. This amount is affected by the entry of bacteria into the digestive tract. $V$. neocaledonicus $\mathrm{L}_{1} \mathrm{~K}_{1} 1$, V. neocaledonicus $\mathrm{L}_{2} \mathrm{~K}_{2} 14$, and $V$. tapetis $\mathrm{L}_{2} \mathrm{~K}_{2} 11$ which was found in green mussels appeared to have a kinship relationship with the bacteria found in previous studies, namely strains $V$. Fluvialis strain VL 5125 that cause foodborne disease found in seafood. $V$. Tapetis can cause vibriosis and foodborne disease in various marine organisms including mollusks (Pailard et al. 2004). V. natriegens $\mathrm{L}_{3} \mathrm{~K}_{2} 20$, have a relationship with the bacteria found in previous studies, namely $V$. shiloni FNS D08 causes foodborne diseases found in seafood.

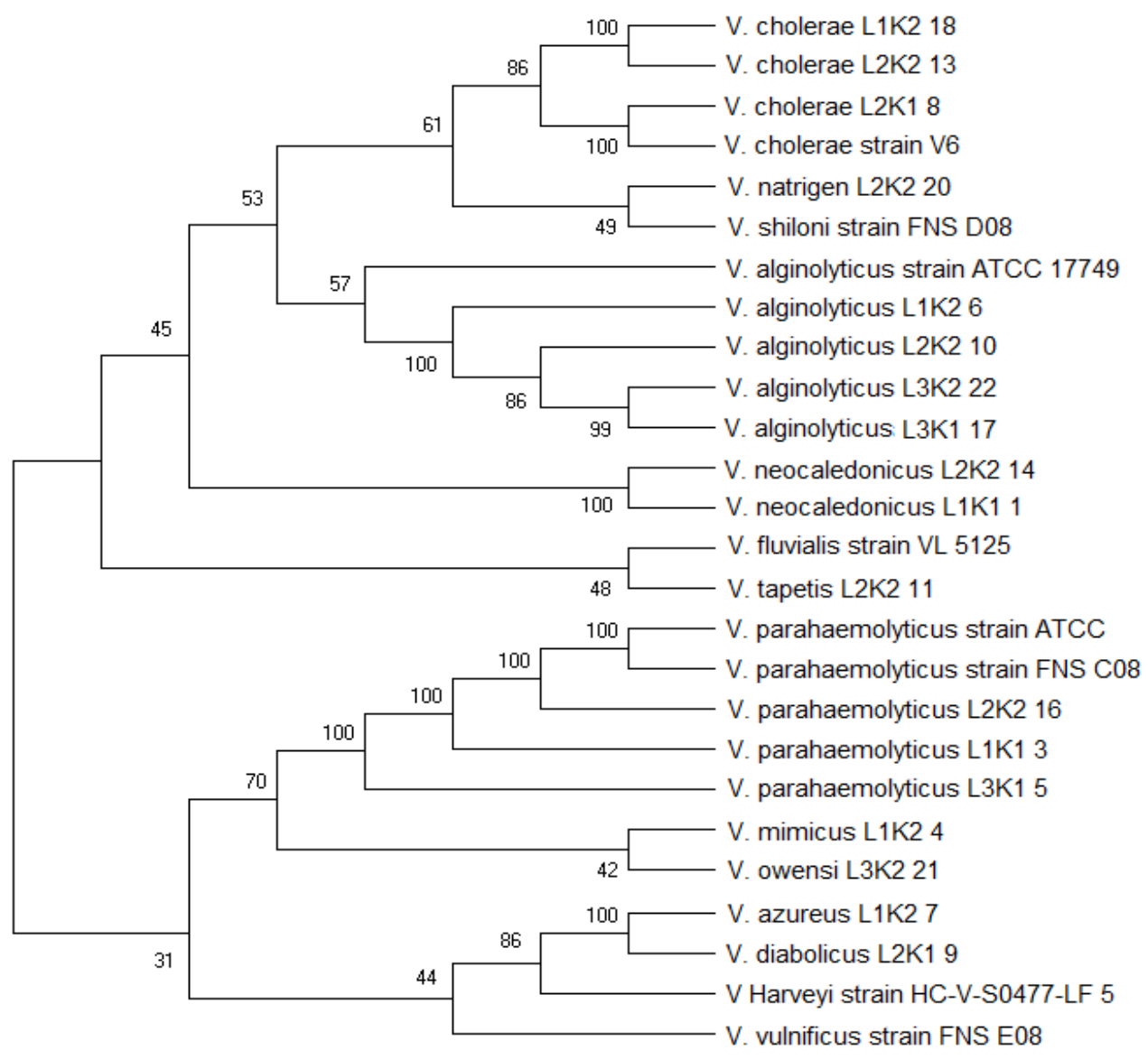

0.10

Figure 4. Phylogenic tree of Vibrio bacteria found in samples green mussels (Perna viridis) 
In the phylogeny tree, the second group in the second branch is bacteria $V$. parahaemolyticus $\mathrm{L}_{3} \mathrm{~K}_{1} \quad 5, \quad V$. parahaemolyticus $\mathrm{L}_{2} \mathrm{~K}_{2} 16$, and $V$. parahaemolyticus $\mathrm{L}_{1} \mathrm{~K}_{1}$ 3 which was found in green mussels appeared to have a kinship relationship with the bacteria found in previous studies, namely strains $V$. parahaemolyticus strain FNS C08, V. parahaemolyticus strain ATCC 17802 that cause foodborne disease found on seafood. in the group, in this second branch, the morphology of the bacterial colonies is green in similarity. $V$. parahaemolyticus has the characteristics fermentative nature, glucose, lactose, sucrose, and with a positive gas production; whereas red methyl and $\mathrm{H}_{2} \mathrm{~S}$ are negative. The molecular identification of $V$. parahaemolyticus has $99 \%$ homology indicating that the pathogen has a base of about 1300bp. $V$. parahaemolyticus has a diameter of $3-5 \mathrm{~mm}$, the center of the colonies is dark green, has a flagellum (Richie 2005). $V$. parahaemolyticus is a gram-negative halophilic bacteria that is distributed in tropical coastal waters throughout the world and causes gastroenteritis (De Paola et al. 2003).

Thermostable direct hemolysin (TDH) is the main virulence factor of $V$. parahaemolyticus. It is not toxic if heated at a temperature of $60^{\circ}-70^{\circ} \mathrm{C}$, but it will be toxic if heated higher than $80^{\circ}$. This case is known as the Arrhenius effect, which explains that this effect is associated with structural changes in proteins that produce fibrils (Fukui et al. 2005). V. diabolicus $\mathrm{L}_{2} \mathrm{~K}_{1} 9$ and $V$. azureus $\mathrm{L} 1 \mathrm{~K} 27$ which was found in green mussels appeared to have a kinship relationship with the bacteria found in previous studies, namely strains $V$. harveyi strain HC-V-S01-0477LF 5 and $V$. vulnificus strain FNS E08. In term of virulence, these bacteria have a specific gene called AcfA for the production of colicin. Colicin is a protein that stimulates the production of ToxR, ToxS, Zonulaa occludens toxins (Zot) and Ace (Turner et al. 2018). V. vulnificus has a green colony color, fermentative properties, positive methyl red, glucose, lactose, and sucrose. During infection, $V$. vulnificus reaches the intestine and then attacks the bloodstream by penetrating the host intestinal mucosal wall which results in disease. Lee et al. (2008) found that RtxA V. vulnificus toxin released by RtxE transport plays a role in the cytotoxicity of $V$. vulnificus against intestinal epithelial cells.

In conclusion, twenty-three bacterial colonies, suspected as Vibrio, were isolated from TCBS media with characteristics including circular bacteria (irregular round), the diameter size of bacterial colonies ranges from 2-5 mm with yellow and green color. The hemolysis test performed on blood agar plate shows that the isolates of $\mathrm{L}_{1} \mathrm{~K}_{2} 6$ dan $\mathrm{L}_{2} \mathrm{~K}_{2} 13$ are $\alpha$ - hemolysis, while the isolates of $\mathrm{L}_{1} \mathrm{~K}_{1} 3$, $\mathrm{L}_{1} \mathrm{~K}_{1} 3, \mathrm{~L}_{2} \mathrm{~K}_{1} 8, \mathrm{~L}_{2} \mathrm{~K}_{2} 16$, and $\mathrm{L}_{3} \mathrm{~K}_{2} 22$ are positive for $\beta$ hemolysis. The molecular analysis involved 18 Vibrio species, and 4 of them represented the Vibrio genus and 14 species represented $97-99 \%$ similarity species in accordance with the $16 \mathrm{~S}$ rRNA sequence in database, namely: V. alginolyticus, V. parahaemolyticus, V. cholerae, Vibrio neocaledonicus, Vibrio mimicus, Vibrio azureus, Vibrio diabolicus, Vibrio tapetis, Vibrio natriegens, and Vibrio owensii. Most of Vibrio species in green mussels are obtained in Goa Cemara beach while the lowest is in
Kwaru beach. From the 10 species of Vibrio obtained in green mussels, V. alginolyticus is spread in all locations of the Yogyakarta beach. Vibrio spp. bacteria found in green clams in coastal tourism areas in Yogyakarta have close phylogenetic relationships with other Vibrio in seafood in Indonesian coastal waters.

Further research is needed to determine the biochemical characteristics and toxic levels of each species of Vibrio spp. as the cause of foodborne disease. An effort to prevent the growth of Vibrio spp. in green mussels and fisheries, in general, is needed in order to reduce the risk of contamination. Then, it is necessary to do in-depth research to obtain Vibrio bacteria with strains which are assumed to be genuine Indonesian strains and it is expected to enrich the strain of Vibrio spp. in NCBI.

\section{ACKNOWLEDGEMENTS}

Warmest gratitude for the seafood sellers that have provided the green mussels for this research and also to P.T. Genetika Science, Jakarta for helping to sequence the Vibrio bacteria.

\section{REFERENCES}

Buwono D. 2004. Jenis Penyakit pada Ikan (Finfish) Budidaya Air Payau. Balai Besar Pengembangan Budidaya air Payau Jepara. http: //www. dkp.go.id/content.php. [Indonesian]

Buxton R. 2013. Blood agar plates and hemolysis protocols. American Society for Microbiology. Washington, D.C.

Campanelli A, Sanchez-Pollita S, Saurat JH. 2008 Ulceration cutanee apres morsure de poulpe: Infection a Vibrio alginolyticus un pathogene emergent. Annal Dermatol Venerol 135: 225-227.

Daniels R, Nicoll L H. 2012. Contemporary Medical Surgical Nursing. 2nd ed. Cengage Learning, Delmar, Canada.

Davies BR, Fanning GR, Madden JM, Steigerwalt G, Gradford HB, Smith HL Jr, Brenner DF. 1981. Characterisation of biochemically atypical Vibrio cholera strains and designation of a new pathogenic species, Vibrio mimicus. J Clin Microbiol 14: 631-639.

De Paola A, Ulaszek J, dan Kaysner CA. 2003. Molecular, serological, and Virulence characteristics of Vibrio parahaemolyticus isolated from Environmental, Food, and Clinical Sources in North America and Asia. Appl. Environ. Microbiol 69: 3999-4005.

De Paola A, Kaysner CA, Bowers J, Cook DW. 2000. Environmental investigations of Vibrio parahaemolyticus in oysters after outbreaks in Washington, Texas, and New York (1997 and 1998). Appl Environ Microbiol 66, 4649-4654.

Eshmat ME, Mahasri G, Rahardja BS. 2014. Analysis of Lead (pb) and Cadmium (Cd) Heavy Metals in Green Mussels (Perna viridis L.) in the Ngemboh Waters of Gresik Regency, East Java. Journal of Fisheries. Faculty of Fisheries and marine affairs. Airlangga University. Surabaya.

Farida H, Susilowati A, Setyaningsih R. 2019. Detection of the number and pathogenicity of Vibrio spp. on green mussels (Perna viridis) in the tourist area of Yogyakarta. Pros Sem Nas Masy Biodiv Indon 5 (2): 334-339.

Fatchiyah A. Widyarti E, Rahayu S. 2011. Biologi Molekuler Prinsip Dasar Analisis. Erlangga, Jakarta. [Indonesian]

Felix F, Nugroho TT, Silalahi S, Octavia Y. 2011. Screening of Indonesian original bacterial Vibrio sp as a cause of shrimp diseases based on 16S Ribosomal DNA-Technique. Trop Mar Sci Technol J 3 (2): 85-99.

Fitriatin, E, Manan A. 2015. Examination of Viral Nervous Necrosis (VNN) in fish with the Polymerase Chain Reaction (PCR) Method. Fish Mar Sci J 7 (1): 2088-5842.

Fukui T, Shiraki K, Hamada D, Hara K, Miyata T, Fujiwara S, Mayanagi K, Yanagihara K, Lida K, Fukusaki. 2005. Thermostable direct 
hemolysin of Vibrio parahaemolyticus is a Bacterial Reversible Amyloid Toxin. Biochemistry 44 (29): 9825-9832.

Hagstrom A, Pinhassi JF, and Zweiefel UL. 2000. Biogeographical diversity among marine bacterioplankton. J Microbial Technol Aquat 21: 231-244.

Hasrida M, Indra R, Yusran U. 2016. Genomic DNA Concentration and Purity Measurement of Anopheles barbirostris. Donggala Research and Development Center, Health Research and Development Agency, Ministry of Health of the Republic of Indonesia, Central Sulawesi. [Indonesian]

Hidayat ARS. 2013. Karakaterisasi Bakteri Genus Vibrio dari Ikan Kerapu (Plectropomus sp.). Jurnal Biogenesis 1 (2): 141-143. [Indonesian]

Ilmiah, Sukenda, Widanarni, Enang H. 2012. Isolation and characterization of Pathogenic Vibrio on Tiger grouper Epinephelus fuscoguttatus. Indonesian Aquaculture Journal 11 (1): 28-37.

Kharirie, K. (2013). Diagnosa Vibrio cholerae dengan metode kultur dan Polymerase Chain Reaction (PCR) pada sampel sumber air minum. Jurnal Biotek Medisiana Indonesia 2 (2): 43-49.

Kumar S, Stecher G, Li M, Knyaz C, and Tamura K. 2018. MEGA X: Molecular Evolutionary Genetics Analysis across Computing Platforms. Mol Biol Evol 35: 1547-1549.

Lee JK, Jung DW, Eom SY, Oh SW, Kim Y, Kwak HS, Kim YH. 2008), Occurrence of Vibrio parahaemolyticus in oysters from Korean retail outlets. Food Control 19 (10): 990-994.

Liu PC, KK Lee. 1999. Cysteine Protease is a major exotoxin of pathogenic luminous Vibrio harveyi in the tiger prawn, Penaeus monodon. Lett Appl Microbiol 28 (6): 428- 430.

Lutz C, Erken M, Noorian P, Sun S, McDougald D. 2013. Environmental reservoirs and mechanisms of persistence of Vibrio cholerae. Front Microbiol 4: 375-380. DOI: 10.3389/fmicb.2013.00375.

Mailoa MN, Setha B. 2011. Karakteristik patogenitas Vibrio sp. diisolasi dari lendir sidat (Anguilla sp). Jurnal Kedokteran dan Kesehatan. [Indonesian]

Marchesi, JR, Sato T. Wightman AJ, Martin TA, Fry JC, Hiom SJ, Wade WG. 1998. Design and evaluation of useful bacterium-specific PCR primers that amplify genes coding for bacterial 16S rRNA. Appl Environ Microbiol 64: 795-9.

Merwad AMA, El-Ghareeb WR, Taisir SM. 2011. Occurrence of some zoonotic Vibrios in shellfish and diarrheic patients with regard to tdh 48 gene in Vibrio parahaemolyticus. J Am Sci 7 (9): 449-459.
Murdinah. 2009. Handling and differentiation of processed green shell products. Squalene 4 (2): 61-71.

National Agency of Drug and Food Control (BPOM). 2008. Regulation of the Head of the Indonesian Food and Drug Supervisory Agency Number. HK. 00.06.1.52.4011. About Determining the Maximum Limit of Microbial Contaminants and Food Chemistry. Jakarta. [Indonesian]

Paillard C, Allam B, Oubella R. 2004. Effect of temperature on defense parameters in Manila clam Ruditapes philippinarum challenged with Vibrio tapetis. Dis Aquat Org 59 (3): 249-262.

Richie JP. 2005. Analisis Bakteri Vibrio Pada Udang Windu (Penaeus monodon) Tambak di Bengkalis Propinsi Riau. [Hon. Thesis] Faperikan UNRI. Pekanbaru. [Indonesian]

Spira, W. M., and P. J. Fedorka-Cray. 1984. Purification of enterotoxins from Vibrio mimicus that appear to be identical to cholera toxin. Infect Immun 45: 679-684.

Supardi I, Sukamto. 1999. Microbiology in Food Processing and Safety. Adikarya IKAPI Foundation \& The Food Foundation. Alumni, Bandung. [Indonesian]

Suryanto D, Irmayanti, Lubis S. 2007. Karakterisasi dan uji kepekaan antibiotik beberapa isolat Staphylococcus aureus dari Sumatera Utara. Majalah Kedokteran Nusantara 40 (2): 104-107. [Indonesian]

Tortora G, Funke B, Case C. 2001. Microbiology an Introduction. 7th ed. Addison Wesley Longman, Inc., New York.

Turner JW, Tallman JJ, Macias A, et al. 2018. Comparative genomic analysis of Vibrio diabolicus and six taxonomic synonyms: a first look at the distribution and diversity of the expanded species. Front Microbiol J. DOI: 10.3389/fmicb.2018.01893.

Wati SA. 2014. Synthesis and Characterization of Hydroxyapatite from Shellfish Feathers Waste (Andara antiquate). [Hon. Thesis]. Faculty of Mathematics and Natural Sciences, University of North Sumatra, Medan. [Indonesian]

Wayan IYW. 2015. The existence of Vibrio cholera pathogenic bacteria in some fishery products sold in traditional markets in Denpasar City. [Hon. Thesis]. Biology Study Program, Udayana University, Denpasar. [Indonesian]

Yital M, Peter HF, Hammes F, Egli T. 2007. Growth of Vibrio cholerae Ol Ogawa Eltor in freshwater. Microbiology 153: 1993-2001. 